\title{
Fate of Surviving Low-Birth-Weight Infants with Coagulation Deficiencies on the First Day of Life
}

\author{
G. M. BRYANT, ${ }^{*}$ M.B., D.C.H., D.R.C.o.G. ; O. P. GRAY, † M.B., F.R.C.P., D.C.H. ; A. J. FRASER, $\ddagger$ S.R.M.L.T., A.R.S.H. \\ A. ACKERMAN,囚 B.PHARM.
}

British Medical fournal, 1970, 4, 707-709

\begin{abstract}
Summary: Fifty-two surviving low-birth-weight infants who had low Thrombotest (Owren) results on the first day, together with the same number of matched controls with higher Thrombotest results, were examined for the integrity of their central nervous system. Gross abnormalities were found in $13.5 \%$ of the low Thrombotest group compared with $1.9 \%$ in the higher group. Minor brain damage syndromes were more common in the low Thrombotest group. The combined brain damage syndromes were $23.1 \%$ in the low Thrombotest group compared with $3.8 \%$ in the higher group.

It is suggested that the causes of the brain damage in the low Thrombotest group are either non-fatal cerebral haemorrhage or intravascular fibrin deposition associated with disseminated intravascular coagulation.
\end{abstract}

\section{Introduction}

Infants of low birth rate who have a severe prothrombin complex deficiency on the first day of life are more likely to die with intracranial haemorrhage than those with a better coagulation status. Fourteen per cent of low-birth-weight infants with low prothrombin complex levels on the first day, as measured by the Thrombotest (Owren), died with cerebral haemorrhage, compared with $5 \%$ of those with higher Thrombotest levels (over 10\%) (Gray et al., 1968). Not all babies with cerebral haemorrhage die, and so it is to be expected that the surviving infants who had a diminished clotting status at birth, and were therefore at risk of cerebral haemorrhage, would show an increased incidence of brain damage. To test this hypothesis we investigated survivors who had a Thrombotest level of $10 \%$ and less on the first day of life, along with carefully matched controls.

\section{Subjects and Methods}

Fifty-two infants in the low Thrombotest group were matched with an equal number of controls who had a Thrombotest greater than $10 \%$. The babies, who were born in the years 1965, 1966, and 1967, were matched for birth weight, date of birth within three months, gestation within four weeks, twinning, type of delivery, complications of pregnancy, and the presence or absence of placental insufficiency (Table I). Other factors which have been noted to be closely associated with a low Thrombotest (Gray et al., 1968) were also matched wherever possible. These are hypoglycaemia, hypoxia during birth, and the Apgar score. A subgroup who had formal intelligence tests were matched also for social class. The method and timing of the Thrombotest estimations were as described previously (Gray et al., 1968).

The infants were examined by one observer (G.M.B.) who was not aware of the Thrombotest result. The clinical inves\footnotetext{
- Medical Officer with Special Responsibilities, Public Health Department, Professor of Child Health, the Welsh National School of Medicine,
Cardiff.

₹ Senior Technician, Department of Obstetrics and Gynaecology, the Welsh National School of Medicine, Cardiff. Senior Research Technician, Department of Child Health, the Welsh
National School of Medicine, Cardiff.
}

tigations were a full medical examination, a record of the motor milestones together with the Ruth Griffiths scale (Griffiths, 1954) of motor development, observation of the gait and fine movements, a cover test for squint, and the Stycar (Sheridan, 1958) screening test for visual defects. Hearing was tested with the Stycar test (Sheridan, 1960a) and the use and understanding of speech by the Ruth Griffiths speech scale. The Sheridan test (Sheridan, 1960b) was used for screening the child's development, and when there was any doubt the full Ruth Griffiths test was performed. This test was done routinely on all the infants studied in the early part of the investigation but was stopped when it became evident that further formal testing of intelligence was superfluous.

The children were seen in their homes when possible, but for geographical reasons some were seen in the clinic. A total of 41 children were seen at home, 24 of whom were in the low Thrombotest group. The age at examination was matched as nearly as possible. The mean age for the children having formal tests of intelligence was 3.4 years in both groups, whereas the group of babies born in the last of the three yearly study periods-1967-had a mean age of 18 months and the controls had a mean age of 19 months (see Table II).

TABLE I.-Matching

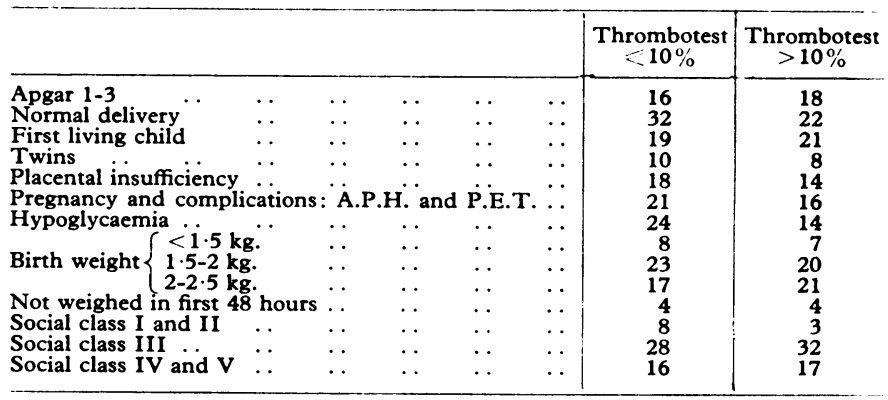

A.P.H. = Antepartum haemorrhage. P.E.T. $=$ Pre-eclamptic toxaemia

TABLE II.-Age at Examination

\begin{tabular}{|c|c|c|c|c|c|c|c|c|c|}
\hline & & \multicolumn{7}{|c|}{ Age in Months } & \multirow{2}{*}{ Total } \\
\hline & & $<12$ & $12-$ & 18- & 24- & 30- & 36- & $40-48$ & \\
\hline $\begin{array}{l}\text { Low Thrombotest } \\
\text { Controls } \ldots\end{array}$ & 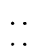 & $\begin{array}{l}3 \\
0\end{array}$ & $\begin{array}{r}8 \\
10\end{array}$ & $\begin{array}{l}15 \\
17\end{array}$ & $\begin{array}{l}9 \\
8\end{array}$ & $\begin{array}{l}7 \\
8\end{array}$ & $\begin{array}{r}10 \\
7\end{array}$ & $\begin{array}{l}0 \\
2\end{array}$ & $\begin{array}{l}52 \\
52\end{array}$ \\
\hline
\end{tabular}

\section{Findings}

Gross Abnormalities.-Seven children in the low Thrombotest group had gross central nervous system abnormalities (13.5\% of the total). By contrast only 1 of the 52 babies $(1.9 \%)$ with a Thrombotest above $10 \%$ had similar findings (see Table III). The difference is significant at $\mathbf{P}=0.03$. In addition to this group of children with gross abnormalities there were five children in the low Thrombotest group and one particular field of development who had one or more features of minor brain damage-namely, clumsy movements associated with minor abnormalities of gait, a speech defect, and a squint. Some children had a lower general developmental score (G.Q.) than that which was appropriate to the 
TABLE III

\begin{tabular}{|c|c|c|c|c|c|c|}
\hline & & & \multicolumn{2}{|c|}{$\begin{array}{c}\text { Thrombotest }<10 \% \\
\text { and }\end{array}$} & \multicolumn{2}{|c|}{$\underset{\text { and }}{\text { Thrombotest }}>10^{\circ} .}$. \\
\hline & & & $\begin{array}{l}\text { Hypo- } \\
\text { glycaemia }\end{array}$ & $\begin{array}{l}\text { Normal } \\
\text { Glucose }\end{array}$ & $\begin{array}{l}\text { Hypo- } \\
\text { glycaemia }\end{array}$ & $\begin{array}{l}\text { Normal } \\
\text { Glucose }\end{array}$ \\
\hline $\begin{array}{l}\text { Severe brain damage } \\
\text { Minor brain damage } \\
\text { No brain damage .. }\end{array}$ & $\begin{array}{l}\cdots \\
\cdots\end{array}$ & $\begin{array}{l}\cdots \\
\cdots\end{array}$ & $\begin{array}{r}2 \\
3 \\
19\end{array}$ & $\begin{array}{r}5 \\
2 \\
21\end{array}$ & $\begin{array}{r}0 \\
1 \\
13\end{array}$ & $\begin{array}{r}1 \\
0 \\
37\end{array}$ \\
\hline Total in group & . & .. & 24 & 28 & 14 & 38 \\
\hline
\end{tabular}

TABLE IV.-Infants with Development not Following the Normal Pattern with Minimal Signs of Brain Damage

\begin{tabular}{|c|c|c|}
\hline No. & Age in Months & Abnormalities \\
\hline 1 & 25 & $\begin{array}{l}\text { Low Thrombotest Group } \\
\text { Slow locomotor development with clumsy gait and } \\
\text { hand movements, a squint, and G.Q. } 82\end{array}$ \\
\hline 3 & 31 & $\begin{array}{l}\text { Lower level of development than would be expected in } \\
\text { the family. G.Q. } 79\end{array}$ \\
\hline 27 & 36 & $\begin{array}{l}\text { Disparity between family and child, and between } \\
\text { different scales. Performance } 72 \text {, G.Q. } 84\end{array}$ \\
\hline 29 & 25 & $\begin{array}{l}\text { Disparity between family and child, and between } \\
\text { different scales, with speech retardation. G.Q. } 87\end{array}$ \\
\hline 75 & 21 & $\begin{array}{l}\text { Slow motor development, with G.Q. } 78 \\
\text { Controls }\end{array}$ \\
\hline 10 & 20 & $\begin{array}{l}\text { Slow motor development-locomotor scale } 70 \text {, speech } \\
\text { scale 11, with hypotonia }\end{array}$ \\
\hline
\end{tabular}

family as a whole (Table IV). The incidence of the combined major and minor brain damage syndromes in the low Thrombotest group is $23.1 \%$ compared with $3.8 \%$ in the control group. This difference is significant at $\mathbf{P}=0.04$. Four children in each group had a squint. There is little difference in the general intelligence quotients of the two groups when the grossly abnormal infants and their controls are removed from the study (see Chart).

The matching was imperfect in the group of children who had blood glucose results of less than $20 \mathrm{mg} . / 100 \mathrm{ml}$. on one or more occasions in the first two days of life. Hypoglycaemia may be an important factor in the aetiology of brain damage, and so the babies who had hypoglycaemia were analysed separately (Table V). Only two who were severely affected had hypoglycaemia. The other six had normal glucose levels, and the distribution of these-five in the low Thrombotest group to one in the control group-is significant at $\mathrm{P}=0.045$.
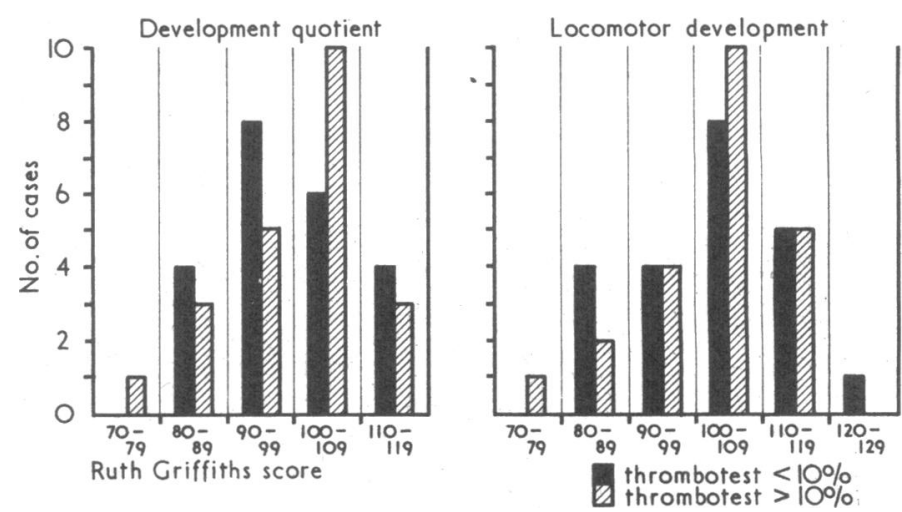

Intelligence quotients of the two groups when grossly abnormal infants and their controls have been omitted.

There were three with slight brain damage who were hypoglycaemic and had a low Thrombotest compared with two with hypoglycaemia in the higher Thrombotest group. These figures, therefore, show that hypoglycaemia did not play an appreciable part in the aetiology of these children's abnormalities.

\section{Discussion}

The results show the less favourable prognosis to bc expected with a low Thrombotest on the first day of life. In addition to increased likelihood of death with intracranial haemorrhage there is the increased hazard of survival with brain damage. There are at least two possible explanations for this. Firstly, the original hypothesis of the diminished coagulability of the blood may lead to a cerebral haemorrhage which is not fatal. This was proved in only one of the babies by lumbar puncture, normally done in this unit only when there is a suspicion of meningitis. Secondly, the mechanism may be that of disseminated intravascular coagulation causing fibrin deposition in the end arteries of the brain. Boyd (1967) showed that babies dying in the first 48 hours of life may have fibrin deposits in various organs. This work has been confirmed with the phosphotungstic acid haematoxylin stain (M. A. Chadd, J. Dew, and S. M. Muxworthy, personal

Table V.-Clinical Details of Affected Cases

\begin{tabular}{l|l|c|c|c|c|c|c|c|}
\hline $\begin{array}{c}\text { Case } \\
\text { No. }\end{array}$ & $\begin{array}{c}\text { Pregnancy and } \\
\text { Labour }\end{array}$ & $\begin{array}{c}\text { Gestation } \\
\text { (weeks) }\end{array}$ & $\begin{array}{c}\text { Birth Wt. } \\
\text { (Kg.) }\end{array}$ & $\begin{array}{c}\text { Thrombo- } \\
\text { test (\%) }\end{array}$ & Apgar & $\begin{array}{c}\text { Neonatal } \\
\text { Progress }\end{array}$ & $\begin{array}{c}\text { Age at } \\
\text { (weeks) }\end{array}$ & Diagnosis \\
\hline
\end{tabular}

Low Thrombotest Group

\begin{tabular}{|c|c|c|c|c|c|c|c|c|}
\hline 5 & Normal & 42 & $2 \cdot 225$ & $<10 \%$ at $12 \mathrm{hr}$. & 2 & $\begin{array}{l}\text { Glucose } 12 \mathrm{mg} . / 100 \mathrm{ml} \text {. at } 1 \\
\text { hr., } 50 \mathrm{mg} \text {. at } 5 \mathrm{hr} \text {. after i.v. } \\
\text { glucose. Cerebral signs for } 4 \\
\text { weeks }\end{array}$ & 28 & $\begin{array}{l}\text { Epilepsy. Spastic quadriplegia. Severe } \\
\text { subnormality }\end{array}$ \\
\hline 31 & First twin & 28 & $1 \cdot 100$ & $<5 \%$ at $1 \mathrm{hr} ., 14 \%$ at $24 \mathrm{hr}$. & 5 & Apnoeic attacks for 5 days & 32 & $\begin{array}{l}\text { Generalized delay in development. } \\
\text { Paralytic squint. G.Q.70 }\end{array}$ \\
\hline 63 & A.P.H. & 32 & 1.925 & $\begin{array}{l}<10^{\circ} \text { at } 24 \mathrm{hr}, 20 \mathrm{ml} . \\
\text { F.F.P., } 15 \% \text { at } 48 \mathrm{hr} .\end{array}$ & 9 & $\begin{array}{l}\text { Apnoeic attacks, I.P.P.V. for } 2 \\
\text { days. Abnormal and dimin- } \\
\text { ished movements }\end{array}$ & 30 & $\begin{array}{l}\text { Spastic quadriplegia. Severe subnor- } \\
\text { mality }\end{array}$ \\
\hline 67 & Fetal distress & 39 & $2 \cdot 125$ & $\begin{array}{l}<5 \% \text { at } 10 \mathrm{hr} ., 30 \mathrm{ml} \text {. F.F.P. } \\
20 \% \text { at } 24 \mathrm{hr} .\end{array}$ & 6 & $\begin{array}{l}\text { Apnoeic attacks with clonic } \\
\text { movements }\end{array}$ & 15 & $\begin{array}{l}\text { Infantile myoclonus. Spastic quadri- } \\
\text { plegia. Severe subnormality }\end{array}$ \\
\hline 93 & First twin & 36 & 1.500 & $7 \%$ at $3 \mathrm{hr}, 19 \%$ at $48 \mathrm{hr}$. & 5 & Apnoeic attacks for 1 day & 28 & $\begin{array}{l}\text { General delayed development. G.Q.67. } \\
\text { Twin II normal }\end{array}$ \\
\hline 99 & Breech & 40 & $2 \cdot 300$ & $<5 \%$ at $12 \mathrm{hr} ., 12 \%$ at $24 \mathrm{hr}$. & 3 & $\begin{array}{l}\text { Intracranial haemorrhage con- } \\
\text { firmed by C.S.F. examin- } \\
\text { ation }\end{array}$ & 30 & $\begin{array}{l}\text { Developed hydrocephalus at } 43 \text { days. } \\
\text { Treated with Spitz Holter valve. } \\
\text { G.Q.60 }\end{array}$ \\
\hline 105 & Normal & 28 & 1.550 & $<5 \%$ at $3 \mathrm{hr} ., 12 \%$ at $7 \mathrm{hr}$. & 8 & Normal & 18 & $\begin{array}{l}\text { Generalized delay in development. } \\
\text { G.Q.38 }\end{array}$ \\
\hline \multicolumn{9}{|c|}{ Affected Control Buby } \\
\hline 22 & Normal & 33 & $1 \cdot 700$ & $>20^{\circ}$ & 7 & Moderate peripheral oedema & 27 & $\begin{array}{l}\text { Spastic diplegia with normal intel- } \\
\text { ligence }\end{array}$ \\
\hline
\end{tabular}

F.F.P. = Fresh frozen plasma.
I.P.P.V. = Intermittent positive-pressure ventilation. 
communication). Appleyard (1968) showed that babies born after an anoxic delivery developed a significant lowering of the Thrombotest at 24 hours compared with those who were not anoxic during delivery.

Possibly the lowered Thrombotest is associated with liver damage due to hypoxia; however, more probably the infants had some degree of disseminated intravascular coagulation resulting from the metabolic acidosis and hypotension associated with intrapartum asphyxia. The intravascular coagulation reduces clotting factors-including prothrombin (factor II), which is consumed-and this will be reflected by a lowered Thrombotest. Some intravascular coagulation undoubtedly occurs in anoxic babies during delivery, as fibrin split products are almost invariably found in the first day of life (M. A. Chadd and S. M. Muxworthy, personal communication). It is suggested that this may be the mechanism in some of the present series. We have several times encountered babies with low Thrombotest who have responded to a dose of fresh frozen plasma by a rise in Thrombotest, but the level has quickly dropned. Some of these babies have shown no sign of haemorrhage at necropsy, so that the rapid drop in factor II level can be explained only by a consumption coagulopathy. The fibrin formed during coagulation, if deposited in small end arteries throughout the brain, could cause multiple areas of cerebral ischaemia, which may explain some of our findings.

We wish to thank Professor Hubert Campbell for help with the statistics; Professor A. C. Turnbull for ever ready support; and the nursing staff of the Cardiff Maternity Hospital for their co-operation at all times.

REFERENCES

Appleyard, J. (1968). Neonatal Research Society.

Boyd, J. F. (1967). Archives of Diseases in Childhood, 42, 401.

Gray, O. P., Ackerman, A., and Fraser, A. J. (1968). Lancet, 1, 545

Gray, O. P., Ackerman, A., and Fraser, A. J. (1968). Lancet, 1, 545 . Press.

Sheridan, M. D. (1958). British Medical fournal, 2, 999

Sheridan, M. D. (1960a). British Medical fournal, 2, 453

Sheridan, M. D. (1960b). The Developmental Progress of Infants and Young Children. London, H.M.S.O.

\title{
Value of Prospective Tissue Typing in Kidney Transplantation between HL-A Identical Siblings
}

\author{
RAMON PATEL, ${ }^{*}$ M.B., M.R.C.P., M.R.A.C.P. ; STEVEN MYRBERG, ${ }^{*}$ B.A.
}

British Medical fournal, 1970, 4, 709-712

\begin{abstract}
Cummary: The predictability of leucocyte typing in kidney transplantation was assessed by an analysis of 37 kidney transplants from sibling donors. Recipients who were identical for the HL-A antigens with their donors gave highly predictable results. In comparison with those siblings who were incompatible or compatible but not identical their grafts functioned earlier, they required less immunosuppression, and had never had any rejections. They also appeared to have less postoperative morbidity. These results indicate that less immunosuppression than is current in many transplant centres could well be used with benefit in HL-A identical sibling transplants. This could reduce the risk of infection and possibly minimize the adverse effects of steroids on wound healing in these patients.
\end{abstract}

\section{Introduction}

Though kidney transplantation is now widely undertaken for certain patients with end-stage kidney disease, rejection and its sequelae continue to be major problems (Hume et al., 1966). Rejections are common during the first three months after transplantation and require large doses of immunosuppressive drugs for their control (Lee et al., 1967). As a result serious complications, including death of the patient, of ten develop in relation to a rejection episode (Starzl, 1964). In general, rejections tend to be less severe and fewer in recipients of bettermatched than in recipients of poorly-matched kidneys (Terasaki et al., 1967). At present HL-A matching is most precise and reliable in the selection of those sibling pairs who inherit the same HL-A chromosome from each of the parents and therefore have an identical HL-A genotype (Amos and Zmijewski, 1967). In our present study the high predictability of leucocyte typing in kidney transplantation between HL-A identical siblings was shown by the results of analysing 37 kidney transplants from sibling donors.

*'The Serotyping Laboratory, Departments of Medicine and Surgery, Peter Bent Brigham Hospital and Harvard Medical School, Boston, Mass.

\section{Materials and Methods}

Between 1 February 1966 and 15 May 1970, 41 patients underwent kidney transplantation from sibling donors at the Peter Bent Brigham Hospital. Of these, 37 were considered suitable for analysis. Three grafts which failed because of hyperacute rejection in sensitized patients and one because of technical reasons were excluded. Details of the surgical technique have already been described (Murray $\ddot{e t}$ al., 1968). All patients received azathioprine and prednisone as the basic immunosuppressive drugs. Sixteen patients received additional immunosuppression as follows: thoracic duct drainage in 5, thoracic duct drainage plus extracorporeal irradiation in 3 , thoracic duct drainage plus antilymphocytic globulin in 4, and antilymphocyte globulin alone in 4 . The drug dosage and the various immunosuppressive regimens (Tilnciy et al., 1970) were independent of the tissue match. Rejection episodes were treated with short courses of $200-400 \mathrm{mg}$. of prednisone which were rapidly tapered according to the response. A three-day course of actinomycin $\mathrm{C}$ was added in cases that responded poorly to prednisone.

Tissue typing was performed according to the microlymphocytotoxicity method of Terasaki and McClelland (1964), with allogeneic anti-HL-A typing sera kindly supplied by Dr. Paul Terasaki, of Los Angeles, California. Thirtythree patients were typed for 12-18 and four for 8 leucocyte antigens. Of the latter patients three died and one was living overseas, so that they could not be retyped with a larger panel of typing sera. At the initial typing, however, two of these patients were considered incompatible with their donors for the leucocyte antigen HL-A2, which even in earlier typings was the most accurately defined of all leucocyte antigens (Patel et al., 1969). A third patient was identical with his donor for three antigens as well as for a number of unspecified sera. Thus despite the fact that typings were done at different periods their accuracy is likely to be seriously questioned in only one of the 37 patients in this series. On the basis of the results of leucocyte typing, the following histocompatibility grades were assigned: recipient- 